\title{
The Comparative of Morphological and Gravity Anomaly Lineaments in West Progo Mountains, Indonesia
}

\author{
Winartia,b, $^{\text {a }}$ Emi Sukiyah ${ }^{\mathrm{a}}$, Ildrem Syafria ${ }^{\mathrm{a}}$, Andi Agus Nur ${ }^{\mathrm{a}}$ \\ ${ }^{a}$ Faculty of Geological Engineering, Universitas Padjadjaran, Bandung, 45363, Indonesia \\ ${ }^{b}$ Faculty of Mineral Technology, Institut Teknologi Nasional Yogyakarta, 55281, Indonesia \\ Corresponding author: "winarti.itny@gmail.com
}

\begin{abstract}
In Yogyakarta Special Region, the West Progo Dome comprises the Nanggulan Formation and Old-Andesite Formation as the oldest formations. The Nanggulan Formation is composed of sedimentary rock with a density of $2.5 \mathrm{~g} / \mathrm{cm}^{3}$, while the Old-Andesite Formation is composed of volcanic rock with a density of $2.7 \mathrm{~g} / \mathrm{cm}^{3}$. Dome morphology is formed by vertical endogenous energy that radiates SE-NW, NE-SW, and E-W. This study aims to describe the correlation between the hill lineaments and gravity anomaly lineaments in the Nanggulan Formation and Old-Andesian Formation. Identification of the hill lineament uses Shuttle Radar Topography Mission (SRTM), while the gravity anomaly lineament uses gravity anomaly map. The standard used in the gravity survey concerning the American Society for Testing and Materials Standard (ASTM). The measurement system utilizes a looping distance of 200-350 meters. The lineaments of the hill and gravity anomaly show the same direction SE-NW. Both lineaments are calculated by fractal dimension (D) utilize the box-counting method. The result of overlaying the two lineaments' fractal dimension produces the same value and the different value. The same fractal dimension value $(D=0.81-1.20)$ indicates whether the hill lineament and gravity anomaly lineament are correlated, while the different fractal dimension values indicate that the two lineaments are not correlated. The fractal dimension value is different due to small intrusions and faults.
\end{abstract}

Keywords - Lineament; dome; gravity anomaly; fractal.

\section{INTRODUCTION}

The hill lineament in the Mountains of West Progo reflects its existence of the rock resistance. This resistant rock is a feature of the Old-Andesite Formation, while the nonresisting rock is a feature of the Nanggulan Formation. In general, the hill lineament is associated with steep and deep valleys. Hill lineament reflects the condition of the rocks below the surface, which also correlates with each other. The gravity data is needed to identify rocks below the surface. The lineament is a line dimension with a specific fractal value, so the calculation results are quantitative. This study aims to describe the correlation between the morphological and gravity anomaly lineaments in the Nanggulan Formation and Old-Andesite Formation. The morphological lineament to use for this research is the hill lineament.

The study field is at the eastern side of the West Progo Dome, Yogyakarta (Fig. 1). The Mountains of West Progo as part of the South Serayu Mountains Physiographical. The mountains have a dome-like shape [1]. The dome was formed by endogenous vertical forces that lifted the mountains, so the lineaments pattern radiated in all directions. In the West Progo Mountains, three regional tectonic patterns contribute to the formation of the dome, it is the Sunda pattern to the SE-NW, the Meratus pattern to the NE-SW, and the Java Pattern to the E-W [1].

The West Progo Mountains are composed of several formations, such as Nanggulan Formation, Old-Andesite Formation, Jonggrangan Formation, and Sentolo Formation. The age of Nanggulan Formation is the Middle EoceneOligocene [2], the Old-Andesite Formation is the Late Oligocene-Middle Miocene [3], the Jonggrangan Formation is the Early Miocene-Middle Miocene, and the Sentolo Formation is the Early Miocene-Pliocene [2]. Nanggulan Formation exposed to the surface by the presence of a thrust fault [2], [3]. This formation consists of sandstone, quartz sandstone, calcareous claystone, interbedded with claystonelignite [3].

Old-Andesite Formation consists of andesite breccia, andesite intrusion, dacite intrusion, basalt intrusion, tuff, lapilli tuff, lapilli breccia, agglomerate, volcanic sandstone, 
and andesite lava, with a thickness of 600 meters. The volcanic rocks were generated from the Menoreh Mountain, Gajah Mountain, and Ijo Mountain activities [2].
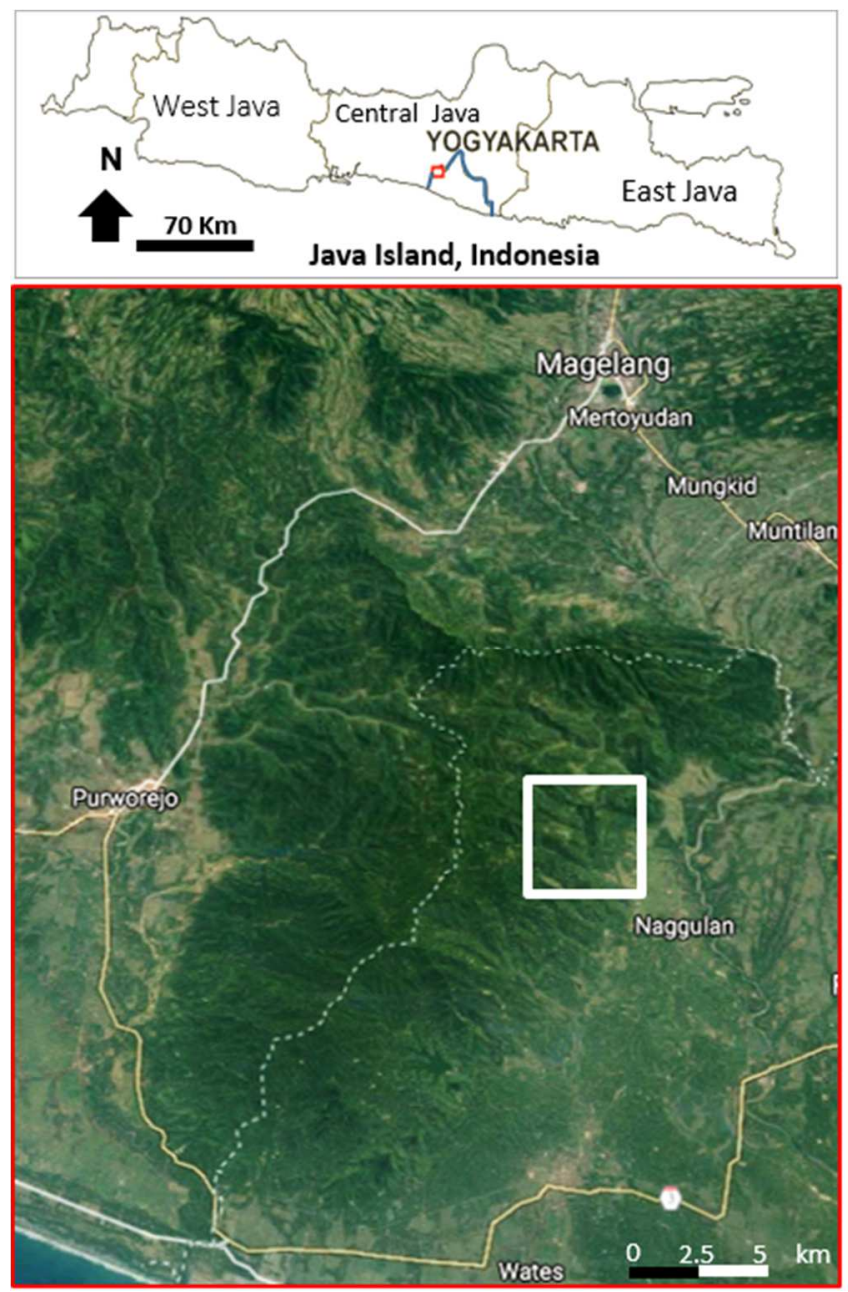

Fig. 1 The area of study is at the West Progo, Yogyakarta

Based on the total number of hill lineaments, scraps, and valleys indicate that Gajah Mountain is the oldest volcanic rock with a lineament of 430, Ijo Mountain at the second volcanic rock with a lineament of 345, and Menoreh Mountain the youngest volcanic rock with a lineament of 249 [2]. The Old-Andesite Formation density is about $2.7 \mathrm{gr} / \mathrm{cm}^{3}$, Nanggulan Formation density is $2.5 \mathrm{gr} / \mathrm{cm}^{3}$, and basement density value is about $2.8 \mathrm{gr} / \mathrm{cm}^{3}$ [3]. This data proves that resistant rock has a density value greater than rocks that are not resistant.

\section{MATERIAL AND METHOD}

\section{A. Method}

The method used is the gravity measurement and the laboratory analysis. The standard used in the gravity survey concerning the American Society for Testing and Materials Standard. The point of gravity measurement is obtained using a grid system spacing between 200 to 350 meters. The gravity measurement always begins and finishes at the base station named the looping system. Determination of the measurement points, taking into account the lineament reflected in the topographic contours.
Each point measured the instrument of coordinate, tool height, elevation, reading scale, and tidal values. The Lacoste Romberg G-1118 gravity meter is used to measure gravity, and the Global Positioning System (GPS) Trimble 4600 LS receiver used to coordinate and elevate measurement. The tool has an accuracy degree of 0.1 meters. The base station is linked by absolute gravity located within the Centre of Volcanology and Geological Hazard Mitigation Yogyakarta.

Laboratory studies include processing gravity data, drawing of hill lineaments, drawing gravity anomaly lineaments, analysis of lineaments direction, and fractal analysis. Gravity data processing uses the Golden Software of Surfer 14 to obtain a Bouguer anomaly map using the gridding and kriging method. Hill lineament was obtained from the Shuttle Radar Topography Mission, while Dips software was used for lineament direction analysis.

\section{B. Gravity}

The gravity method measures the mass density variation at a measurement point from another measurement point. The result of a measurement causes a deviation from the normal gravity value, and are known as an anomaly of gravity. The distinction among gravity fields observed with theoretical gravity is gravity anomaly. Simple Bouguer Anomaly correction value is an addition of observation gravity value with elevation correction to the reduction of the theoretical gravity value [4], with follows the formula:

$$
\Delta \mathrm{g}_{\mathrm{BA}}=\mathrm{g}_{\mathrm{obs}}+\mathrm{g}_{\mathrm{Elev}}-\Delta \mathrm{g}_{\emptyset}
$$

Where $\Delta g_{B A}$ : value of Simple Bouguer Anomaly correction, $g_{\text {obs }}$ : gravity value of observation data, $g_{\text {Elev }}$ : with elevation correction, $\Delta g_{\emptyset}$ : theoretical gravity value.

The anomaly of the gravity value must all be corrected to get the Bouguer anomaly value, including the correction of free-air, correction of Bouguer, correction of topography, and correction of tidal, mathematically formulated [5]:

$$
\Delta \mathrm{g}_{\mathrm{B}}=\mathrm{g}_{\mathrm{m}}+\left(\Delta \mathrm{g}_{\mathrm{FA}}-\Delta \mathrm{g}_{\mathrm{BP}}+\Delta \mathrm{g}_{\tau}+\Delta \mathrm{g}_{\text {tide }}\right)-\Delta \mathrm{g}_{\mathrm{n}}
$$

Where $\Delta \mathrm{g}_{\mathrm{B}}$ is Bouguer anomaly, $\mathrm{g}_{\mathrm{m}}$ is result of observation data, $\Delta \mathrm{g}_{\mathrm{FA}}$ is gravity value of free air correction, $\Delta \mathrm{g}_{\mathrm{BP}}$ is gravity value of Bouguer correction, $\Delta g_{\tau}$ is gravity value of topography correction, $\Delta \mathrm{g}_{\text {tide }}$ is gravity value of tidal correction, and $\Delta \mathrm{g}_{\mathrm{n}}$ is gravity value of mathematics calculation.

To obtain the Bouguer anomaly with the same height, the plane reduction is performed on using the Dampney mass method. This method considers the source of the anomaly as a below the surface mass plane. Dampney equation has been formulated [6]:

$$
\Delta \mathrm{g}(\mathrm{x}, \mathrm{y}, \mathrm{z})=\mathrm{G} \int_{-\infty}^{\infty} \int_{-\infty}^{\infty} \frac{(\rho(\alpha, \beta, \mathrm{h})(\mathrm{h}-\mathrm{z}) \mathrm{d} \alpha \mathrm{d} \beta)}{\left\{(\mathrm{x}-\alpha)^{2}+(\mathrm{y}-\beta)^{2}+(\mathrm{z}-\mathrm{h})^{2}\right\}^{\frac{3}{2}}}
$$

Where $\Delta \mathrm{g}(\mathrm{x}, \mathrm{y}, \mathrm{z})$ is topographic gravity anomaly value, $\rho(\alpha, \beta, h)$ is the distribution of density contrast in the mass point plane $(\mathrm{h}-\mathrm{z}), \mathrm{z}$ is the vertical axis that reflects the distance between topography and the reference Spheroid in a positive direction to the center of the earth, and $h$ is the depth of the equivalent source of point mass measured from the reference Spheroid. The gravity method is used to identify geological sub-surface structures, including gravity anomaly 
to determine the faults depth and direction of the structures in the sub-surface [7], gravity anomaly to determine the control structure of the plateau [8], gravity to determine uplift and tectonic evolution [9].

\section{Fractal}

Fractal is geometric shape resulting from repetition and sequence of a set of simple shapes [10]. The combined simple form has the properties of self-affinity, self-similarity, selfsquaring, and self-inverse in order to obtain a simple, regular object. Each resulting shape is characterized by either a noninteger number is called a dimension of fractal [10]. One of the methods to obtain fractal dimensions is the box-counting method or grid method. The box-counting method's principle is to fill the shape with rectangular boxes of a certain size, so that the object is seen as a whole even though it has a complicated shape, equation of mathematics [11]:

$$
\mathrm{D}_{\mathrm{B}}=\lim _{\mathrm{r} \rightarrow 0} \frac{\log \mathrm{N}(\mathrm{r})}{\log \left(\frac{1}{r}\right)}
$$

Where: $D_{B}$ is a box-counting dimension, $N(r)$ is the overall number of sized boxes, and $r$ is needed to cover the curve completely. A fractal dimension is an approach to quantitative analysis. Many geological phenomena can be analyzed using the fractal dimension, as follows:

- The correlation of structural lineaments with deposits of hydrothermal ore [12].

- The correlation between fault depth and migration of ore-forming fluids [13].

- Comparing the porosity measurement results from the calculation of fractal dimension with laboratory [14].

- The correlation between sub-surface geological conditions and morphological characteristics [15].

- The relationship between earthquakes and rock grains' size, the correlation between folds, topography, and fractures, the correlation between fracture concentration and the productive geothermal field [16].

- Deposition, folding, shorelines, water flow, burial patterns below the surface [10].

- Determining the relationship between lineaments and soil degradation processes [17]

- Structural geology phenomenon [18].

\section{RESULT AND DISCUSSION}

Hill lineaments are shown in the study area in Fig. 2. The lineament has the main SE-NW direction in Fig. 3. The measurement of gravity is carried at 48 points, and the data from the measurement results are shown in Table 1. The residual Bouguer anomaly value was derived from the results of the gravity data processing.

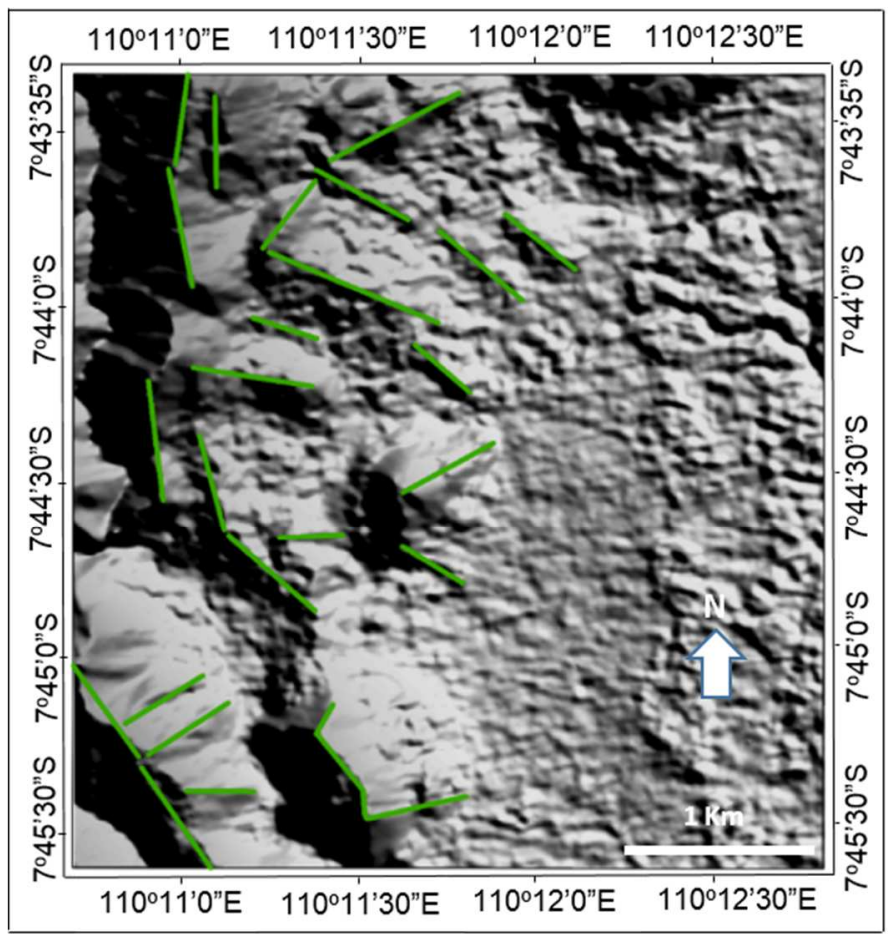

Legend:

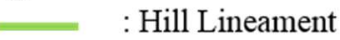

Fig. 2 Hill lineament of Shuttle Radar Topography Mission identified

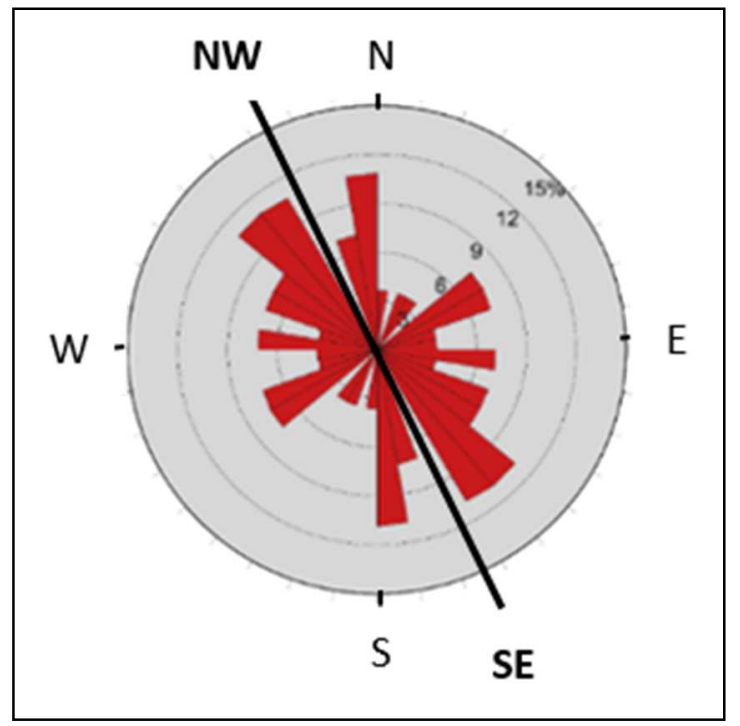

Fig. 3 Hill lineament direction SE-NW

The gravity anomaly lineament direction results show the SE-NW in Fig. 4, so the direction of the gravity anomaly lineament is the same as the direction of the hill lineament. The Bouguer anomaly map is generated based on the residual Bouguer anomaly value. Some of the Bouguer anomaly's lineaments can be made by looking at the map (Fig. 5). 
TABLE I

GRAVITY DATA MEASURED IN FIELD

\begin{tabular}{|c|c|c|c|}
\hline Point & $\begin{array}{c}\text { gobservation } \\
\text { (mgal) }\end{array}$ & $\begin{array}{c}\text { Bouguer } \\
\text { Anomaly } \\
\text { (mgal) }\end{array}$ & $\begin{array}{l}\text { Residual Bouguer } \\
\text { Anomaly (mgal) }\end{array}$ \\
\hline G1 & 978183.46 & 156.29 & 110.91 \\
\hline G2 & 978170.66 & 155.32 & 124.05 \\
\hline G3 & 978180.21 & 155.59 & 113.19 \\
\hline G4 & 978174.46 & 155.61 & 120.25 \\
\hline G5 & 978188.39 & 154.84 & 102.19 \\
\hline G6 & 978182.80 & 154.65 & 108.62 \\
\hline G7 & 978176.08 & 154.38 & 116.71 \\
\hline G8 & 978164.35 & 154.83 & 131.35 \\
\hline G9 & 978154.07 & 160.60 & 154.98 \\
\hline G10 & 978168.72 & 156.52 & 129.79 \\
\hline G11 & 978163.17 & 158.67 & 140.70 \\
\hline G12 & 978169.99 & 155.94 & 126.64 \\
\hline G13 & 978177.78 & 157.26 & 120.08 \\
\hline G14 & 978180.18 & 157.13 & 116.677 \\
\hline G15 & 978176.96 & 157.79 & 122.21 \\
\hline G16 & 978172.34 & 159.13 & 130.57 \\
\hline G17 & 978163.17 & 160.28 & 143.69 \\
\hline G18 & 978168.21 & 159.07 & 135.32 \\
\hline G19 & 978159.16 & 159.68 & 147.70 \\
\hline G20 & 978160.34 & 162.04 & 150.74 \\
\hline G21 & 978177.49 & 160.21 & 126.65 \\
\hline G22 & 978176.86 & 160.22 & 127.74 \\
\hline G23 & 978168.93 & 160.94 & 138.49 \\
\hline G24 & 978171.30 & 160.98 & 136.18 \\
\hline G25 & 978160.69 & 163.21 & 153.41 \\
\hline G26 & 978163.68 & 162.18 & 147.69 \\
\hline G27 & 978155.48 & 164.88 & 163.35 \\
\hline G28 & 978166.28 & 163.48 & 147.04 \\
\hline G29 & 978174.47 & 161.84 & 133.78 \\
\hline G30 & 978181.46 & 160.45 & 122.88 \\
\hline G31 & 978173.30 & 163.62 & 138.69 \\
\hline G32 & 978177.47 & 162.35 & 131.17 \\
\hline G33 & 978178.89 & 163.56 & 132.14 \\
\hline G34 & 978184.47 & 162.59 & 123.65 \\
\hline G35 & 978178.35 & 164.83 & 135.43 \\
\hline G36 & 978187.41 & 161.96 & 118.97 \\
\hline G37 & 978183.86 & 160.25 & 119.29 \\
\hline G38 & 978176.93 & 163.63 & 134.94 \\
\hline G39 & 978175.78 & 163.74 & 136.87 \\
\hline G40 & 978188.92 & 161.76 & 116.72 \\
\hline G41 & 978186.57 & 162.80 & 121.69 \\
\hline G42 & 978178.74 & 162.87 & 131.54 \\
\hline G43 & 978182.50 & 162.05 & 125.81 \\
\hline G44 & 978183.74 & 161.76 & 122.75 \\
\hline G45 & 978180.37 & 160.51 & 124.58 \\
\hline G46 & 978174.36 & 161.81 & 134.23 \\
\hline G47 & 978183.86 & 160.25 & 119.29 \\
\hline G48 & 978188.99 & 159.85 & 112.60 \\
\hline
\end{tabular}

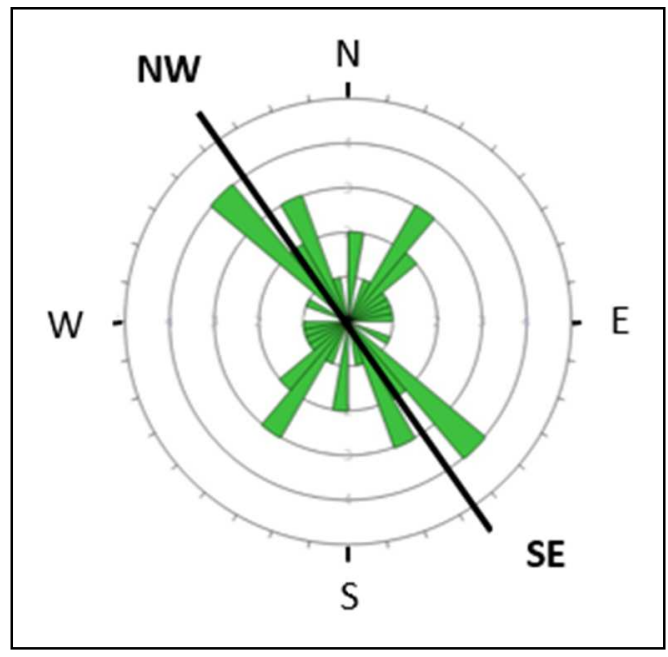

Fig. 4 Gravity anomaly lineament direction SE-NW

The fractal dimension (D) values of the hill lineament and gravity anomaly lineament range from 0.00-1.50. To determine the correlation between hill lineament and gravity anomaly lineament, the dimension of the fractal values of two lineaments is overlayed in Fig. 6.

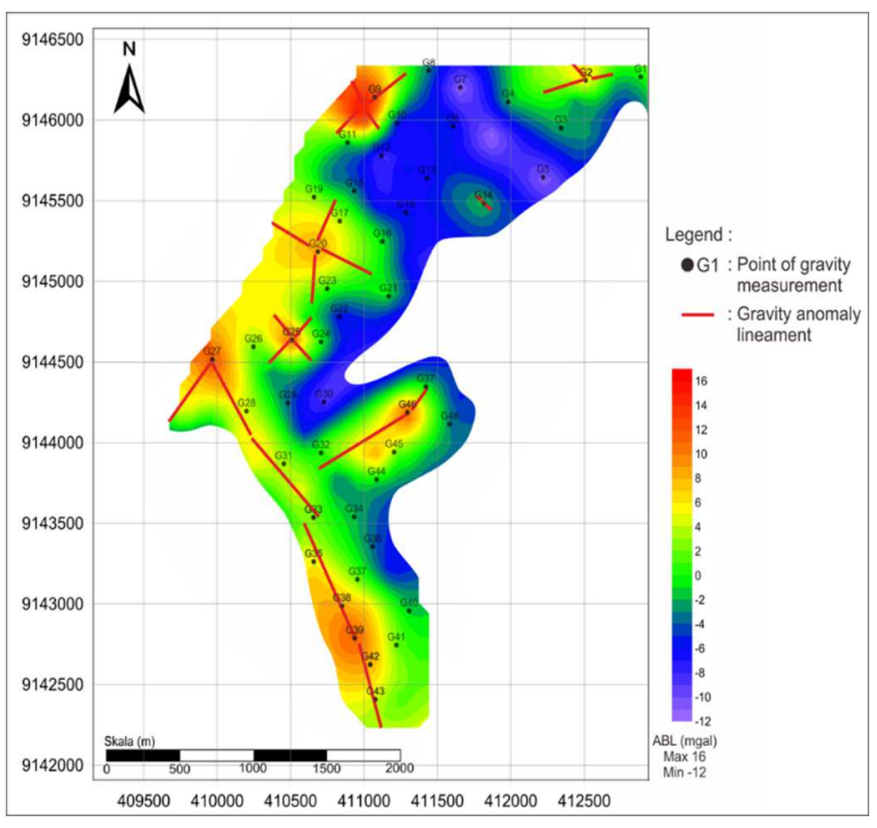

Fig. 5 Gravity anomaly map and gravity anomaly lineament

The result of overlaying the two lineaments fractal values is that there are locations with the same fractal value, and there are locations with different fractal values. The same fractal dimension (symbol $\mathrm{C}$ ) value has $\mathrm{D}=0.81-1.20$. This indicates that the hill lineament on the surface correlates with the gravity anomaly lineament below the surface, so they are correlated. Different fractal dimension value indicates that the hill lineament on the surface do not correlate with the gravity anomaly lineament below the surface so that the two are uncorrelated. The factor that causes the fractal dimension value is different because the igneous rocks appearing as intrusions are small. Most likely, buried igneous rock has a greater dimension so that the hill lineament does not correlate with the gravity anomaly lineament. 
Small size andesite intrusions are found based on surface outcrops (Balak area) in Fig. 7. A high-density value with a wide distribution is identified by the Bouguer anomaly map in the area to interpret if the igneous rock has large dimensions below the surface. Besides, the factors that cause the hill lineament to be unrelated to the gravity anomaly lineament can be caused by faults. The position of the shifting rocks on the surface and sub-surface results in an uncorrelated lineament. Faults are one of the factors causing the Nanggulan Formation to be exposed to the surface.

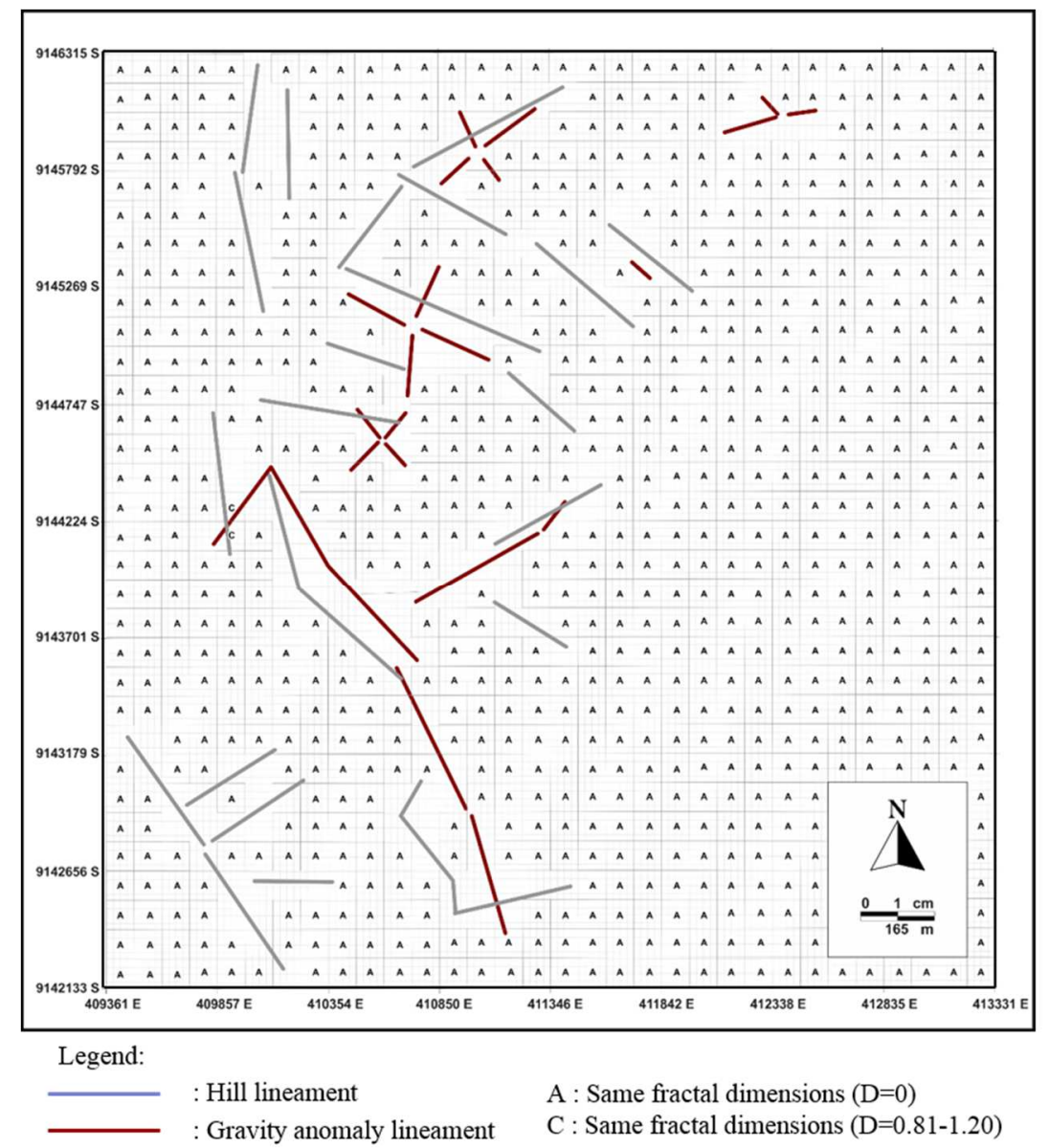

Fig. 6 Overlay the fractal dimension between the hill lineament and gravity anomaly lineament

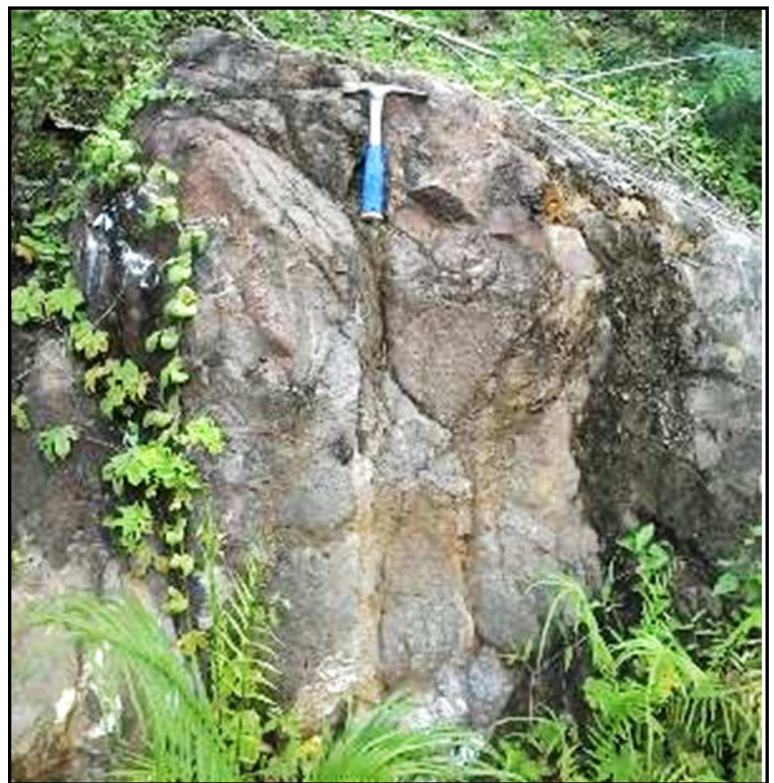

Fig. 7 Andesite intrusion outcrops in Balak area

\section{CONCLUSIONS}

The Old-Andesite Formation consists of resistant rocks with a density of $2.7 \mathrm{~g} / \mathrm{cm}^{3}$, while the Nanggulan Formation consists of non-resistant rocks with a density of $2.5 \mathrm{~g} / \mathrm{cm}^{3}$. Based on these data, there is a correlation between rock and density. In general, the hill lineament and gravity anomaly lineament direction are of the same direction, namely SE-NW. The result of the fractal dimension overlay indicates the same value and different values between the two lineaments. The fractal dimension is equal to $0.81-1.20$, indicating if the hill lineament on the surface correlates with the gravity anomaly lineament below the surface. There are different fractal dimensions in several places, which indicate that the hill lineament on the surface does not correlate with the gravity anomaly lineament below the surface, which is caused by small intrusions and faults.

\section{ACKNOWLEDGMENT}

The authors are grateful to the Institut Teknologi Nasional Yogyakarta management for supporting the study. 


\section{REFERENCES}

[1] S. Ildrem, B. E., and S. A., "Geotectonic Configuration of Kulon Progo Area , Yogyakarta Konfigurasi Tektonik Daerah Kulon Progo , Yogyakarta," Indones. J. Geosci., vol. 8, no. 4, pp. 185-190, 2013.

[2] A. Widagdo, S. Pramumijoyo, and A. Harijoko, "The MorphotectonoVolcanic of Menoreh-Gajah-Ijo Volcanic Rock In Western Side of Yogyakarta-Indonesia," J. Geosci. Eng. Environ. Technol., vol. 3, no. 3, p. 155, 2018.

[3] Winarti, E. Sukiyah, I. Syafri, and A. A. Nur, "Springs phenomena as contacts between nanggulan and old andesite formations at eastern west progo dome, Indonesia," Int. J. GEOMATE, vol. 19, no. 74, pp. 167-175, 2020 .

[4] H. AH and E. M. AAG, "Gravity-Based Structural Modelling of Awataib Area, River Nile, State, Central Sudan,” J. Earth Sci. Clim. Change, vol. 08, no. 01, pp. 1-7, 2017.

[5] A. I. Obasi, A. O. I. Selemo, and J. S. Nomeh, "Gravity models as tool for basin boundary demarcation: A case study of Anambra Basin, Southeastern Nigeria," J. Appl. Geophys., vol. 156, pp. 31-43, 2018.

[6] C. N. G. Dampney and O. City, "gz(x, y, 2) =," vol. 34 , no. 1, pp. 3953, 1969.

[7] K. P. R. Malquaire, O. A. M. L. Clotilde, N. Nfor, N.-M. Théophile, and M.-D. Eliezer, "Determination of Structural and Geometrical Parameters of the Kribi-Campo Sedimentary Sub-Basin Using Gravity Data," Int. J. Geosci., vol. 08, no. 09, pp. 1210-1224, 2017.

[8] B. Apollinaire et al., "Subsurface Structural Mapping Using Combined Terrestrial and Grace Gravity Data of the Adamawa Plateau (NorthCameroon)," Int. J. Geosci., vol. 08, no. 07, pp. 869-887, 2017.

[9] Z. Wang and G. Fu, "Gravity analysis of the offset between crustal structure and topography in the Liupan Shan, northeast Tibetan Plateau," Earth, Planets Sp., vol. 72, no. 1, pp. 1-9, 2020.
[10] S. B. Kusumayudha, M. T. Zen, S. Notosiswoyo, and R. S. Gautama, "Fractal analysis of the Oyo River, cave systems, and topography of the Gunungsewu karst area, central Java, Indonesia," Hydrogeol. J., vol. 8, no. 3, pp. 271-278, 2000.

[11] B. S. Raghavendra and D. N. Dutt, "Computing fractal dimension of signals using multiresolution box-counting method," World Acad. Sci. Eng. Technol., vol. 37, no. 1, pp. 1266-1281, 2010.

[12] C. Lyu, Q. Cheng, R. Zuo, and X. Wang, "Mapp ping Spatial Di istribution Cha aracter ristics of Lineam ments Extracted fr rom Remote Se ensing I Image Using Frac al and Multif actal Models t r Chen," $J$. Ear th Sci., vol. 28, no. June, pp. 315-332, 2017.

[13] C. Ni, S. Zhang, Z. Chen, Y. Yan, and Y. Li, "Mapping the Spatial Distribution and Characteristics of Lineaments Using Fractal and Multifractal Models: A Case Study from Northeastern Yunnan Province, China," Sci. Rep., vol. 7, no. 1, pp. 1-11, 2017.

[14] Y. Liu, B. Xiao, B. Yu, H. Su, and B. Xiao, "FRACTAL ANALYSIS of DIGIT ROCK CORES,” Fractals, vol. 28, no. 6, pp. 1-13, 2020.

[15] A. A. Nur et al., "Fractal Characteristics of Geomorphology Units as Bouguer Anomaly Manifestations in Bumiayu, Central Java, Indonesia," IOP Conf. Ser. Earth Environ. Sci., vol. 29, no. 1, 2016.

[16] M. Behyari, J. Nouraliee, and D. Ebrahimi, "Structural Control on the Salmas Geothermal Region, Northwest Iran, from Fractal Analysis and Paleostress Data," Acta Geol. Sin., vol. 92, no. 5, pp. 1728-1738, 2018.

[17] S. Hosseini, G. R. Lashkaripour, N. H. Moghadas, M. Ghafoori, and A. B. Pour, "Lineament mapping and fractal analysis using SPOT-ASTER satellite imagery for evaluating the severity of slope weathering process," Adv. Sp. Res., vol. 63, no. 2, pp. 871-885, 2019.

[18] R. Basirat, K. Goshtasbi, and M. Ahmadi, "Determination of the fractal dimension of the fracture network system using image processing technique," Fractal Fract., vol. 3, no. 2, pp. 1-9, 2019. 